\title{
Plants and biochemical defence
}

\section{John Friend}

Phytoalexins. Edited by John A. Bailey and John W. Mansfield. Pp.334. ISBN 0-216-91162-1. (Blackie/Halsted: 1982.) $£ 28, \$ 79.95$.

THE existence of phytoalexins as antifungal compounds actively accumulated by plants was first proposed in 1940 to explain the response of potato tuber tissue to inoculation with avirulent and virulent races of Phytophthora infestans. Although the major sesquiterpenoid phytoalexin from potato was not isolated until 1968 , in the intervening period phenolic and terpenoid phytoalexins were identified in orchids, sweet potato, carrots, peas and French beans. Many more plants have since been investigated for their ability to produce phytoalexins in response to environmental stress, as well as to challenge not only by fungi by also by bacteria and viruses and by salts of heavy metals.

The aim of the editors of Phytoalexins was to review in detail the compass of current research into these compounds; with the aid of a battery of international authorities on the various topics, this is what they have done and excellently so. Broadly the book falls into two parts, the first of which deals mainly with the chemical study of phytoalexins.

Since the majority of such compounds have been isolated from the Leguminosae and the Solanaceae a separate chapter is devoted to each of these families (by J.L. Ingham and J. Kuć, respectively), whereas the phytoalexins from all the other families are covered in a further contribution by D.T. Coxon. Ingham's chapter is particularly valuable in that it includes chromatographic and spectroscopic data which can be used for the separation and identification of phytoalexins. In his comprehensive review of phytoalexin biosynthesis A. Stoessl separates the phytoalexins according to their biosynthetic origin from shikimic acid, acetate-polymalonate and mevalonate; he also emphasizes the value of stressed tissue for biosynthetic studies.

In the remaining contributions, comprising the second part of the book, the accent is on the possible roles of phytoalexins in plant diseases. The reactions involved in the metabolism of phytoalexins both by microorganisms and plants are described by H.D. VanEtten and colleagues, and D.A. Smith discusses the toxicity of phytoalexins and their metabolites. J.W. Mansfield then provides a detailed description of phytoalexin accumulation in the interaction of several leguminous and solanaceous plants with fungi, bacteria, viruses and nematodes. It is clear from these accounts that pathogenicity cannot necessarily be explained by the ability of the invading pathogen to tolerate or metabolize phytoalexins, although in many cases of resistance there is sufficient accumulation of phytoalexins to account for this resistance; nevertheless other factors such as suberization and lignification must be taken into account.

In his review of the mechanisms of phytoalexin accumulation, J.A. Bailey indicates that the underlying mechanisms leading to the build-up of all classes of phytoalexin may be similar. He proposes that host cell death releases an endogenous elicitor which triggers the enzymes involved in phytoalexin biosynthesis, and points out that specificity would involve control of cell death. The final chapter, written by the two editors themselves, is an excellent summary of work on phytoalexin function to date and of possible ways in which it could proceed in the future.

The overall presentation, particularly of the formulae and diagrams, is good and there are very few errors. Moreover there is a comprehensive bibliography with each chapter, and a compound and an organism index at the end of the book (though, unfortunately, no author index). Phytoalexins will be the standard work on the subject for some considerable time; as such it is an essential reference volume for all workers in plant disease physiology and phytoalexin biosynthesis.

John Friend is Professor and Head of the Department of Plant Biology at the University of Hull.

\section{Flies in the lab}

\section{Michael Ashburner}

A Handbook of Drosophila Development. Edited by Robert Ransom. Pp.289. Hbk ISBN 0-444-80366-1; pbk ISBN 0-44480418-8. (Elsevier Biomedical: 1982.) Hbk Df1.250, \$116; pbk Dfl.100, $\$ 46$.

THE EDITOR of this collection of reviews on the development of Drosophila states his objective as being:

to provide a useful and practical research aid, which may be kept close at hand on the researcher or students [sic] own bookshelf.

This, however, is not a "handbook" in the German tradition; the fact that you can actually pick it up with one hand establishes that. Yet its chapters do provide useful, if not over-scholarly, reviews of the embryonic and imaginal development and structure of Drosophila. There is, of course, some overlap with Vol.2 of The Genetics and Biology of Drosophila (Academic, 1978) - a work in which I must declare some interest - but except for two

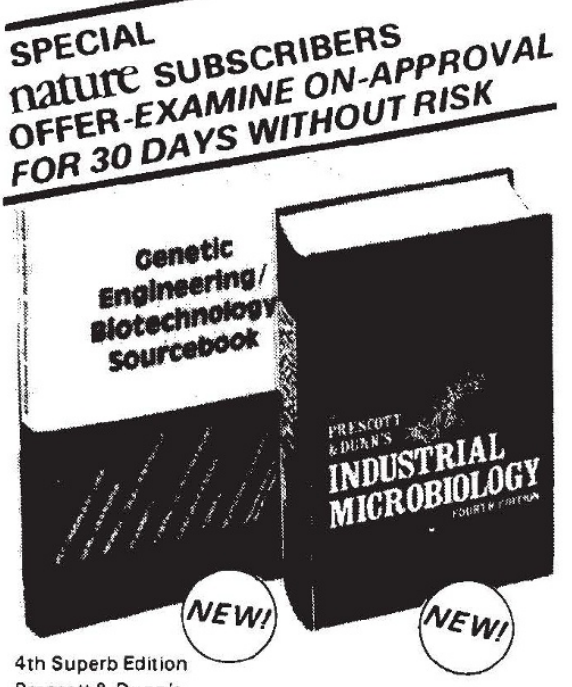

Prescott \& Dunn's

\section{Industrial Microbiology}

Edited by Gerald Reed

Vice President. Amber Laboratories USA

The up-to-date guide and reference tool to industrial technology and applications in the microbiology of foods and food ingredients - with a special section on biological production of fuel alcohol

Macmillan Hardcover $896 \mathrm{pp} \quad \mathbf{4} 42.50$
ISBN O 33333630551982

\section{Genetic Engineering/}

\section{Biotechnology Sourcebook}

Never before publishedl Profiles of 1,529 recent and ongoing genetic engineering/biotechnology research projects funded by 122 US government and non-profit organizations.

Covers research affecting: $\star$ Pharmaceuticals $\star$ Medicine and Diagnosis $\star$ Agriculture $\star$ Food Processing $\star$ Energy $\star$ Chemicals.

Reveals for each project Nature and objectives of research Funding source and money awarded

Names and addresses of individual researchers.

Special Yellow Pages reference section tells you at a glance who's researching what, where, when and how. Macmillan Sottcover $350 \mathrm{pp} \quad \mathbf{f 5 2 . 5 0}$

IS\&N 03333414811982

Place your on-approval order today!

\section{GLOBE} BOOK SERVICES LTID

Canada Road, Byfleet, Surrey KT14 $7 \mathrm{JL}$. England Tel: Byfleet (09323) 40397

A MEMBER COMPANY OF MACMILLAN PUBLISHERS LTD.

P--

EXAMINE ON 30 DAYS

\section{APPROVAL}

To: Ian Jacobs, Globe Book Services Ltd. FREEPOST, To. lan Jacobs, Globe Book Services Lid., FREEPOST (Please tick books required)

Please send me copies of $\square$ Genetic

Engineering/Biotechnology Sourcebook at $\mathbf{5 2 . 5 0}$ copies of 1 dustrial Microbiology at or- $f 42.50$ plus P\&P (UK $f 2$ Overseas $\{3$ ) on 30 days approvat if plus PQP (UK 22 . Overseas 3 i on 30 days approval. If within that period for a full refund

Tick preferred method of payment

$\square$ I enclose cheque for $f$

$\square$ Charge my credit card $f$

$\square$ Visa $\square$ Access $\square$ American Express DDiners

Card No. Expiry date

Signature

(Orders cannot be accepted without a signature)

Name (PLEASE PRINT)

Address Postcode 